\title{
How to Go Beyond an Ontotheology of the Human Subject? Anxiety in Kierkegaard and Heidegger
} Jeffrey S. Librett University of Oregon

By examining Martin Heidegger's critique of Søren Kierkegaard, this essay reconsiders the limits that an ontotheology of the subject may or may not impose on investigations of the relations between being and time. I begin by summarizing briefly both Heidegger's rejection of subject-centered thought and his critique of Kierkegaard as an example of such thought. I then delineate the sense in which, and gauge the extent to which, in The Concept of Anxiety Kierkegaard unsettles both the modal-ontological categories on which such subject-centered thought is based and the "vulgar" notion of time that, according to Heidegger, traditionally attends the invocation of these categories. Finally, I indicate briefly some ways in which Heidegger's thought remains partially beholden to an ontotheology of the subject. The more general implication is certainly not, however, that Kierkegaard outdoes Heidegger in some sort of competition in the deconstruction of metaphysics. Rather, this approach to the question of the metaphysics of the subject by way of the anxiety-analyses of Heidegger and Kierkegaard suggests that the exact character of such a metaphysics and the specific meaning of "subject" and "subjectivity" remain open and pressing questions, especially given that Heidegger's fundamental ontology (and his Seinsdenken), as well as Kierkegaard's critique of Hegelian systematicity, remain marked by traditional notions of sovereign selfdetermination, and its ontology.

Jeffrey S. Librett is Professor of German and Head of the Department of German and Scandinavian at the University of Oregon. He is the founding editor of this journal, and the author of The Rhetoric of Cultural Dialogue: Jews and Germans from Moses Mendelssohn to Richard Wagner and Beyond (Stanford: Stanford University Press, 2000), Orientalism and the Figure of the Jew (New York: Fordham University Press, 2015), and numerous essays and translations.

Since now my attempts at thinking too are often brought into relation to Kierkegaard, and otherwise the classification as "philosophy of existence" has become utterly self-evident and, as it were, everything in advance is sunken into the grave of this title, something must be said toward the clarification of the 
concept of existence in Being and Time (Martin Heidegger $)^{1}$

The 'substance' of the human is not spirit as the synthesis of soul and body, but existence" (Martin Heidegger). ${ }^{2}$

Amongst the various questions raised by Heidegger's appropriation of Kierkegaard, the one on which I focus here is the question of the limits placed by an ontotheology and anthropology_an ontoanthropotheology_of the "subject" on investigations concerning the relations between being and time. Does conceiving of the human as a "subject" necessarily falsify or distort the relationship between the human and being and/or time? Is the "subject" necessarily always conceived as Vorhandenheit, which is to say, as existentia = Wirklichkeit in a manner that obscures its "authentic" temporality? How far does Kierkegaard take us - and in what ways does he block us from proceedingalong the road to understanding how human beings exist in time, and how time structures human existence? In order to pursue these and related questions, I begin by expanding briefly on Heidegger's reasons for rejecting a philosophy of the subject, and then I outline his characterization of Kierkegaard as representing such a philosophy. This preparation enables me to consider then with reference to The Concept of Anxiety whether or not Kierkegaard simply remains within a metaphysics of subjective presence in Heidegger's sense, and whether or not his conception of time is simply reducible to the "vulgar" notion of time, Innerzeitigkeit or "within-timeness," as Heidegger argues. (I ignore the question and role of pseudonyms here, although I by no means dismiss their importance more generally for an interpretation of Kierkegaard's works, and especially of the "subject" in these works.) Having pursued these questions, finally, I very briefly consider whether or not Heidegger's own model of Dasein, including his later thinking of the truth of Being, entirely exceeds the metaphysics of the subject. This trajectory leads to the suggestion that, on the one hand, Kierkegaard goes 
somewhat farther toward Heidegger's thought than Heidegger can or will quite give him credit for, and that, on the other hand, Heidegger, through the limitations of his own thought, remains closer to Kierkegaard than he can acknowledge. Such a provisional result, which attempts less to be original than to be reasonably judicious, is not meant to invalidate Heidegger's thought, but to help us in a small way to gauge, in relation to Kierkegaard and through the rereading of certain Kierkegaardian motifs from The Concept of Anxiety, where Heidegger is to be situated in his progress toward his own stated philosophical ambitions. More generally and importantly, it reopens the question of the subject beyond the limits of Heidegger's critique of Kierkegaard.

I.

Before coming to Heidegger's characterization of Kierkegaard's thought as an onto-anthropo-theological subjectivism that is problematically metaphysical in its conception of being as presence and of truth as restricted to the truth of beings, we need to recall what Heidegger says about the notion of the "subject" in general in Being and Time. ${ }^{3}$ The problem with the construal of the human being as a subject for Heidegger is that one always presupposes for this subject an ontological status of Vorhandenheit, or "(objective) presence," as Stambaugh translates it, and which Heidegger chooses explicitly from the outset of Sein und Zeit as the German terminological equivalent of existentia (42; 41). In construing the human being as a subject, one unwittingly treats it like a thing. (In this sense, traditional philosophical conceptions of the subject never treat it, as it were, subjectively enough.) The ontological determination of Da-sein as "je meines" does indeed entail an ontic self-evidence that the "who" of Da-sein is always "I"— an ego, subject, or self, which sustains itself as identical through the changes of attitudes and experiences. But this implication of a present [vorhanden] subjektum, "lying at the base of" consciousness, is something like a transcendental illusion, because my Being is mine always also as my having-tobe it, i.e. it does not ground me here and now except insofar as it awaits my reassumption of it there and then. My being is temporally dispersed. This is- 
very quickly stated - why the mode of presence of Vorhandenheit "is the mode of being [Seinsart] of beings unlike Dasein" $(115 ; 112)$. Its factuality is accessible though a theoretical or "gazing constatation" [in einem hinsehenden Feststellen] $(135 ; 132)$, unlike the facticity of Da-sein, which appears as thrownness in moods. The human is not a subject, because the being of a subject is always conceived as punctually self-coincident, a present moment, whereas human being as existence in Heidegger's sense is constituted principally by the temporal "ecstases." When Heidegger arrives (in § 65) at the determination of temporality as the meaning of care (the care that he has determined as the being of $\mathrm{Da}$ sein), the reason for his initial refusal of metaphors of subjectivity will attain a heightened explicitness, as the three ecstases of time-future [Zukunft], havingbeen [Gewesenheit], and presencing [Gegenwärtigen]_appear as what makes possible [ermöglicht] $(324 ; 310)$ the "articulated structural whole of care" (324; 310). The meaning of care-which Heidegger in turn associates with Dasein itself in the process of its self-understanding-is precisely this temporality that makes care "possible" $(324,310)$. Temporality—and not a punctually present subject—is thus the "ground" of Dasein (436; 413). Having retraced very briefly Heidegger's argument against subjectivity, we need now to consider how Heidegger situates Kierkegaard with respect to this problematic of the subjective.

II.

Fourteen years after the publication of Sein und Zeit, in the first part of the lectures on Schelling from 1941, entitled Die Metaphysik des deutschen Idealismus, while the War and the Holocaust are well underway, Heidegger is working hard to distinguish himself not only from existentialism in general (and specifically in Jaspers and Kierkegaard), but also from subjectivism. He quotes at length and responds bitterly, for example, to Nikolai Hartmann's recent accusations to this effect, but that particular polemic is not our topic here. In the process of marking his distance from the "philosophy of existence," Heidegger characterizes Kierkegaard's thought of "existence" as one that identifies "existence" with "reality" [Wirklichsein], and yet also with "subjectivity," with 
"consciousness," and with human individuality. For Heidegger, that is, Kierkegaard belongs generally to the metaphysical tradition of determining existentia as reality qua presence (17), but also more narrowly to the modern tradition that determines this reality as subjectivity.

At the same time, however, Kierkegaard is for Heidegger precisely not a philosopher, and this makes Heidegger ambivalent about his work, because the non-convergence of a thinker with philosophy per se can be a good thing, as well as a bad one, from Heidegger's perspective. First, Kierkegaard is not a philosopher in the sense that, as a mere faithful Christian, he is as it were subphilosophical. For example, Heidegger suggests that Kierkegaard does not do justice either to Hegel or to his own debts to Hegel, and so Heidegger says that he "renounces philosophy utterly and exists only as a believer" [schlechthin der Philosophie entsagt, und nur als Gläubiger existiert] (25). But secondly, Kierkegaard is more than philosophical, and in this sense a thinker who cannot simply be assimilated into either theology or philosophy or even more broadly metaphysics: he is "more theological than ever a Christian theologian and more unphilosophical than ever a metaphysician could be" (19). And in this he is "incomparable. . . he must stand alone: neither theology nor philosophy can assimilate him to its history" [theologischer denn je ein christlicher Theologe und unphilosophischer als je ein Metaphysiker sein könnte. . . . unvergleichlich; er muß in sich stehenbleiben; weder die Theologie noch die Philosophie kann ihn in ihre Geschichte einreihen] (19). And of course, Heidegger himself strives to be beyond philosophy — he says explicitly in these lectures that Being and Time as a project or mode of thinking is "not yet or no longer philosophy" (28)—so in this context it is certainly not clear that being more unphilosophical than any metaphysician would be a bad thing.

In short, on the one hand Kierkegaard belongs to the modern metaphysics of subjectivity to the degree that he does not manage to reconfigure or redetermine the concepts he inherits in a new and explicitly rigorous way that would question specifically being and time along the line of thinking Heidegger develops. Furthermore, although trying to push in some respects beyond the 
metaphysics of subjectivity and orthodox Lutheran theology, Kierkegaard nonetheless, according to Heidegger, determines "existence" as "being in the truth of Christian faith an individual human before God. (Being a Christian in reality, 'in' the real—before the absolutely real.)" (26). In other words, Kierkegaard adheres to a metaphysics of subjectivity that Heidegger will later call ontotheological, in which the presence of God as highest being confirms the presence of the subject-soul in its being. As he puts it in these Schelling-lectures: "The cosmos and the ground of the cosmos, God, theos, is a human who has been thought out and thought upwards [hinaus- und hinaufgedacht(...)] to the level of the gigantic and the unconditional" (72). A certain humanism, or anthropocentrism, goes hand in hand with religion as ontotheology, constituting an ontoanthropotheology, in this metaphysics, to which Kierkegaard still in part belongs.

But on the other hand, Kierkegaard in his role both as "religious thinker" (19) and also as "writer" (26) becomes an unavoidable encounter and even perhaps an unsurpassable obstacle_-an dem man nicht vorbeikommt (26)—by virtue of having "realized. . . a singular sojourn [einzigartigen Aufenthalt] of selfreflection [or reflection on the self: Selbstbesinnung] within the nineteenth century" (26).

III.

Of the various ways in which Kierkegaard might be seen to push or gesture beyond a metaphysics of presence (and hence beyond the subject in Heidegger's sense), the one l'd like to consider here is his displacement of the ontology of essence and existence in his analysis of possibility in The Concept of Anxiety. I will argue first that he displaces possibility from its positions as the opposite of reality, and as the negation of impossibility. This means that he undermines also the decidability of the distinctions between essence and existence, and between essentiality and inessentiality. Secondly, I will explore some of the ways in which this displacement reasserts itself in Heidegger's own conceptualization of possibility. Heidegger's repeated claims that Kierkegaard 
made no progress in matters of ontology or on the level of the existenzial, but remained limited to the ontic, or the existenziell, appear in this light to have more the character of interested disavowals than of dispassionately reliable philosophico-historical claims.

What happens, then, to the sense of "possibility" in the process of Kierkegaard's mobilization of the term within his analysis of anxiety? For example, what happens to possibility when Kierkegaard claims that "anxiety is freedom's actuality as the possibility of possibility" (42), and speaks of the "anxious possibility of being able" (44), phrases that inaugurate a philosophicohistorical chain passing by way of Heidegger's possibility of impossibility to Levinas's "impossibility of every possibility," or not being able to be able, only the first of which I will consider here? ${ }^{4}$

It can be said that, in identifying a mood with ontological modal categories by way of an anthropological-metaphysical concept such as that of the freedom to act that characterizes the human (what Kant had called "causality of the will"), Kierkegaard is subjectivizing and humanizing ontology. But one can say with at least equal plausibility that he is ontologizing the psycho-somatic or the psychophysiological here. One might even say, in a more Heideggerian idiom, that Kierkegaard is examining the mode of being of the human-freedom's actuality-as a relation to being in its guise as possibility of possibility. Yet of course what is important is not just that Kierkegaard is dealing with modal categories in his definition of anxiety, but how he is doing so.

To get started: the notion of freedom as "possibility of possibility" modalizes a modality, or potentiates it (to use the language of romantic reflexionphilosophy through Schelling), such that possibility presents itself in its most proper (or real) form-because anxiety is the encounter with possibility in an emphatic sense-as something other than an actuality or reality. If the most real or actual form of possibility ("freedom's actuality") is its mere possibility, then-at least in this instance-the opposition between possibility and actuality is being undermined or exceeded, suspended or placed in question, precisely as it is being maintained. For the possibility (of possibility) is here its actuality. 
Conversely, in the anxiety-text actuality presents itself as remaining pervaded by possibility, as overwhelmed by possibility-e.g. the anxiety of the good and the anxiety of evil arise out of the possibility that reinstalls itself with every movement of actualization (or every renewal of the qualitative leap into sin). And in the concluding section, as Kierkegaard contrasts the lightness of actuality with the weightiness of possibility, actuality becomes as it were more possible than possibility itself, and possibility becomes more actual than actuality. Finally, when Kierkegaard determines anxiety as the "intermediate term" in the "transition" from possibility to actuality (49), he situates anxiety as precisely this limit where each modal category turns into its opposite, or the very site of the ongoing selfdeconstruction of the opposition between possibility and actuality. ${ }^{5}$ Since this latter opposition is traditionally the equivalent of that between essence and existence, I am suggesting that Kierkegaard operates in this text also a deconstruction of the opposition between essence and existence. ${ }^{6}$ The encounter with an "infinity of possibility" (61) in anxiety is the encounter not only with the proliferation of essences, or significations, but also with their tendency to de-realize the world or to usurp its palpability, while at the same time existence or reality takes on the significance of the essential, for example in the sense that action augments its urgency.

Moreover, under the pressure of Kierkegaard's analysis, the notion of possibility appears at times difficult to distinguish from impossibility itself. In light of the fact that there is an abyss between possibility and actuality-an abyss that remains despite the tendency of the terms to become undecidable-possibility is radically altered through the "qualitative leap" of the act, such that even that subset of the possible chosen for realization never allows its realization as such or unaltered. This would be perhaps one implication of the "absolute future" David Kangas talks about in Kierkegaard's Instant. ${ }^{7}$ It is certainly one meaning of the "prohibition" that language utters in The Concept of Anxiety-the cloud of "no" resting on all of possibility, connecting us as it were in advance with the impossibility. The possible is impossible. 
Thus, although he works out a "psychological" discourse that would supplement a religious, "dogmatic" one, and although he retains the conceptuality of body and soul as realized and uplifted into a spiritual unity (and other basic conceptual elements of Occidental metaphysics), Kierkegaard also unsettles ontological categories crucial to the metaphysics of presence and of the subject-as the presence of realized possibility. Before coming back to the question of how Kierkegaard's account of temporality in the anxiety book relates to Heidegger's account in and around Being and Time, let us briefly consider some of the terms that in Heidegger correspond to the distorted or reconfigured modality terms we've been recalling from Kierkegaard.

The most obvious point, which I cannot exhaustively develop here, is that the emphatic notion of "possibility" passes like a kind of original postmetaphysical sin from Kierkegaard to Heidegger such that while Heidegger appropriates this notion in his own manner, he also certainly seems to be powerfully influenced by Kierkegaard. Indeed, one can plausibly speak of what Harold Bloom called "anxiety of influence" in this relationship, and precisely concerning the theory of anxiety itself, and its contexts. In his discussion of anxiety in Sein und Zeit, Heidegger describes the falling prey [Verfallen] of everyday inauthenticity as fleeing into the world (of taking-care and concern) from something that is not in the world as a real presence, either vorhanden or zuhanden. This flight is based on anxiety before "being-in-the-world," which is radically indeterminate, a nothing, as in Kierkegaard, and indeed a nothing of possibilities. "What crowds in upon us [Was beengt] is not this or that, nor is it everything objectively present [alles Vorhandene] together as a sum, but the possibility of things at hand in general [die Möglichkeit von Zuhandenem überhaupt], that is, the world itself" $(187 ; 181)$. And in turn anxiety is anxious about [um] being-in-the-world as an indefinite plurality of possibilities of being for being-there $(187 ; 181)$. Anxiety "throws Dasein back upon that for which it is anxious, its authentic potentialityfor-being-in-the-world [sein eigentliches In-der-Welt-sein-können]. Anxiety individuates Dasein to its ownmost being-in-the-world which, as understanding, projects itself essentially upon possibilities [Die Angst vereinzelt das Dasein auf 
sein eigenstes In-der-Welt-sein, das als verstehendes wesenhaft auf Möglichkeiten sich entwirft ]" (187; 181-2). Thus, along with that for which it is anxious, anxiety discloses Dasein as being-possible [Mit dem Worum des Sichängstens erschließt daher die Angst das Dasein als Möglichsein]. (187-8; 182) Not only does anxiety, here too, turn about the encounter with possibility, but possibility is more than just possibility in Heidegger; as in Kierkegaard, it tends to absorb human existence into itself. Anxiety in Heidegger too is associated with radical freedom with respect to possibilities, for example as: "being free for. . . the authenticity of its being as possibility which it always already is [Freisein für. . die Eigentlichkeit seines Seins als Möglichkeit, die es immer schon ist] "(188;182). ${ }^{8}$ The structure of possibility in Heidegger, whereby it undecidably impinges on reality, is quite similar to the structure of possibility in Kierkegaard.

Indeed, Heidegger develops further and with greater explicitness the intimacy of the relationship between possibility and impossibility that is more implicit in Kierkegaard. Heidegger describes the existential-ontological structure of death as: "the possibility of the absolute impossibility of Dasein. Thus, death reveals itself as one's ownmost, nonrelational, insuperable [unüberholbar] possibility" (250-1; 241). By running out ahead [Vorlaufen], or anticipating one's death, Dasein can recognize to a greater or lesser extent that this possibility of impossibility is already realizing itself, that the possible has already become impossible. In addition, as a possibility assumed or taken on, it has a reality of another sort, namely that of resoluteness. "As anticipation of possibility, beingtoward-death first makes this possibility possible and sets it free as possibility [Das Sein zum Tode als Vorlaufen in die Möglichkeit ermöglicht allererst diese Möglichkeit und macht sie als solche frei ]" (262; 251). In a manner similar to Kierkegaard, Heidegger intermingles and unsettles the distinct modal-conceptual identities of possibility and reality-as he also constantly (especially in the later work) mixes essence and existence when he uses Wesen and Anwesen in verbal forms-so as to describe and evoke the uncanniness of the relation between the human being and being as such in its various modal aspects. ${ }^{9}$ 
IV.

If Kierkegaard's displacement of the traditional opposition between possibility and reality or essence and existence can thus be seen to go beyond a subjectivist version of the metaphysics of presence as simple Vorhandenheit, and to play a prominent role in Heidegger's development of the motifs of being able to and being possible, then what about Kierkegaard's approach to time? Heidegger argues in Sein und Zeit that Kierkegaard remains caught up in the "vulgar" notion of time, "Innerzeitigkeit," which sees the human as situated at any given now-instant in time rather than as constituting its being through temporalization in the three "ecstases" of futurity, having-been-ness, and presentation. Let us see how this argument works, and to what extent Kierkegaard's account of time accords with the picture Heidegger paints of it.

Heidegger offers his main comments on Kierkegaard's theory of temporality in a brief footnote within section $\S 68$ of Sein und Zeit, where he is detailing the temporal structures of the three main aspects of the disclosure of Being in Dasein in terms of understanding [Verstehen], attunement [Befindlichkeit], and falling prey [Verfallen]. Let me set the scene in a formal way, without spelling out the meanings of all the terms that comprise the scene, in order to recall the context of the footnote we need to consider. While understanding is primarily grounded in the future [Zukunft], attunement primarily in having-been [Gewesenheit], and falling prey in the present [Gegenwart], each aspect of the disclosure of Being involves all three temporal "ecstases" (346; 330). It is in his treatment here of the temporal structure of understanding that Heidegger makes his polemical remarks against Kierkegaard. Since understanding, which is primarily futural, can take on authentic and inauthentic forms, associated with resoluteness and irresoluteness respectively, Heidegger distinguishes between two structures. Authentic understanding relates to the future by anticipation [Vorlaufen], to the present as the moment [Augenblick], and to the past as repetition [Wiederholung], in the sense of the return to the past that would reabsorb it into the space of resoluteness. Inauthentic understanding 
constitutes the future as "awaiting" or "expecting" [Gewärtigen], the present as making present [Gegenwärtigen], and the past as forgetfulness [Vergessenheit]. Within this set-up, it is the moment, or Augenblick, that-not surprisinglyprompts Heidegger's brief polemical footnote.

Kierkegaard saw the existentiell phenomenon of the Moment in the most penetrating way, which does not mean that he was also as successful in the existential interpretation of it. He gets stuck in the vulgar concept of time and defines the Moment with the help of the now and eternity. When Kierkegaard speaks of "temporality," he means human being's being-in-time. Time as within-time-ness knows only the now, but never a moment. But if the moment is experienced existentially [existenziel/], a more primordial temporality is presupposed, although existentially [existenzial] inexplicit. (338; 323)

But how does Heidegger himself define the "moment"?

In resoluteness, the present is not only brought back from being distracted by what is taken care of closest at hand, but is held in the future and having-been. We call the present that is held in authentic temporality, and is thus authentic, the Moment [Augenblick]. This term must be understood in the active sense as an ecstasy. It means the raptness [Entrückung] of Dasein that is held in resoluteness, a raptness in what is encountered as possibilities and circumstances to be taken care of in the situation. The phenomenon of the Moment can in principle not be clarified in terms of the now. . . " "in which" something comes into being, passes away, or is objectively present [vorhanden]. $(338 ; 323)$ What, then, is the ontological-temporal structure of the Moment in Heidegger and what is the ontological-temporal structure of Kierkegaard's Moment, and how does one compare/contrast with the other?

In Heidegger, the Moment takes shape as a stepping out of or back from the preoccupation with the activities of the everyday (as taking care and concern 
for beings in the world-Besorgen and Fürsorge) into the pure interplay between futurity and pastness (or the casting forward of understanding and the being-cast of mood). "Resolutely, Dasein has just taken itself back out of falling prey, in order to be that much more authentically in the "moment" (>>Augenblick $<<$ ) gazing at the situation $>>$ there $<<" ~(328 ; 313)$. The experience of the "moment" is one that opens up the elements of the "situation" through a "decision" or "resolution" $(338 ; 313)$. But the decision holds the present in futurity and havingbeen: it views the situation in the framework of time. The Augenblick is thus much more like the presentation of the absence of the present, the presentation or vision of the present's anticipatory and repetitive structure, than like the presentation of its presence. It is the "moment" of the unveiling of the temporality of existence rather than of its evasion through the immersion in any pure now.

How, then, does Kierkegaard's "moment" measure up against this "moment"? Are they, as it were, contemporaneous? And how accurate is Heidegger's critique of Kierkegaard's thinking of time? Restricting ourselves to the central elements of Kierkegaard's arguments, let us recall that the moment is explicitly not, in The Concept of Anxiety, the ever-disappearing present in time, or time as "infinite succession." Of the latter, Kierkegaard says explicitly that it flows immediately away and cannot constitute of itself a basis for temporality (85). Rather, only a certain "synthesis" of this fleeting instant with eternity constitutes temporality in its dimensionally differentiated sense. This "synthesis" articulates body with soul, or spirit (as substance), on the level of temporality, as the moment, except that, according to Kierkegaard, there is no third term in the "synthesis" of time with eternity: their "synthesis" must be understood as remaining in some sense unachieved, or tenuous at best: it is a "relation of time to eternity and ... the reflection of eternity in time" (85). Since Kierkegaard argues that in the "passing by" that is time as infinite succession there is no "present" and therefore no past or future, on the one hand Heidegger does not do Kierkegaard justice by suggesting that Kierkegaard places the "moment" in "being-in-time." When Heidegger says, "Time as within-time-ness knows only the now but never a moment," it seems clear that Kierkegaard would agree with him. 
On the other hand, it is impossible to deny that Kierkeggard "defines the moment with the help of the now and eternity." However, it remains to be seen in what respects such a definition is at odds with Heidegger's approach to the three ecstases of time, and in what respects it accords with that approach. Let us begin with the eternal. The eternal, for Kierkegaard, is "the present," as "an annulled succession," and "the present is full" (86). So in the contradiction constitutive of "the moment," emptiness confronts fullness, and passing-by confronts presence. Thus far, Kierkegaard certainly seems to ground temporality qua infinite succession in a supratemporal substance. And this aspect of his text cannot, I think, be denied.

But it is not the only aspect. For example, when Kierkegaard says that time as infinite succession is "time past" (87), then he is delineating perhaps something like the "having-been-ness" or Gewesenheit that Heidegger envisions. The eternal, on the other hand, is associated with the future:

the future in a certain sense signifies more than the present and the past, because in a certain sense the future is the whole of which the past is a part, and the future can in a certain sense signify the whole. This is because the eternal first signifies the future or because the future is the incognito in which the eternal, even though it is incommensurable with time, nevertheless preserves its association with time (89). ${ }^{10}$

If the eternal is the future, which Heidegger conceives as the ekstasis of the "ahead of oneself [sich-vorweg]," while time is the past, which Heidegger characterizes as "already being in (the-world) [schon sein in (der-Welt-)]" and the moment is the "touch" or "intersection" of these two contradictory dimensions, which would correspond approximately to Heidegger's "being alongside of (the existents encountered within the world) [sein bei (innerweltlich begegnendem Seienden)]" (192; 185), a being-alongside-of that is anxiety itself because it is flooded with possibility, then Kierkegaard's temporality-concept comes to seem closer to Heidegger's existential analysis than it may have initially appeared.

Of course, one should not efface the differences, and especially the substantial, spiritual, theological character of "the eternal" in Kierkegaard's 
account, which provides the frame for a Christian anthropology of the moment, rather than a fundamental ontology. Yet while Kierkegaard does construct the present moment out of the "synthetic" tension between an eternal presence that is potentially up ahead and a process of time's empty now passing by, he does not, I think, simply situate the human being "in time," or construe the present moment in terms of the punctual Vorhandenheit of a subject, as Heidegger's critical remarks from 1941 suggest. While Kierkegaard does not leave behind some of the basic elements of a Christian ontotheological metaphysics, he does describe the human experience of temporality as constituted in the conflictual interplay of futurity and pastness, an interplay that generates a "moment" fraught with anxiety in the face of an indeterminable interpenetration of possibility and actuality. ${ }^{11}$

\section{V.}

In the attempt to evaluate some particularly important aspects of Heidegger's comments on, and relationship to, Kierkegaard's thought, I have argued thus far that while Kierkegaard's thought moves to some extent within the ontotheological metaphysics of presence and of human subjectivity to which Heidegger wishes to consign it, Kierkegaard also makes important gestures in ontological and temporal analysis that push away from this metaphysics. First, he displaces and unsettles the opposition between possibility and reality, essence and existence, providing Heidegger with new "possibilities" that he then "realizes" in new ways. And second, he provides an account of "the moment" as crossing between temporal and eternal that in some regards anticipates the Heideggerian account of the moment in terms of the three temporal ecstasies and in particular the partial withdrawal from "falling prey" to the entanglement with the presence of innerworldly beings. It remains for us to consider in a last turn of the argument: to what extent does Heidegger himself escape the metaphysics of presence and of the subject, and the onto-theology (conflation of Being with the highest being) that often goes hand in hand with these? I will restrict myself, concerning this extraordinarily complex theme, to two brief remarks. 
First, there remains, especially for the later Heidegger, the question of what Karl Löwith called Heidegger's "godless theology," i.e. the question of the extent to which the thinking of Being is separated from the theology of the highest being, and from the entanglement of the latter with various forms of the thought of the subject as absolutely present to itself. ${ }^{12}$ To anchor this enormous question here to just two passages: in the second Schelling lectures, Heidegger writes for example: "The word 'there,' the 'there,' means precisely this clearing for Being. It is the essence of Dasein to be this 'there'. [Das Wort $>>D a<<$, das $>>D a<<$ meint eben diese Lichtung für das Sein. Das Wesen des Daseins ist es, dieses $>>D a<<z u$ sein]" (60)]. But if it is the essence of Dasein to be the clearing "for" Being, then Being is that for the sake of which Dasein exists, and having one's raison d'être in service to God (as God's subject) is not far off, even if it goes without saying here. And similarly, Heidegger says that Da-sein is called human only because "the human is assigned or allotted to Da-sein in order to become in Da-sein 'inständig'" [>>der $<<$ Mensch dem Da-sein eigens zugewiesen wird, um im Da-sein inständig zu werden] (61), "inständig" meaning normally "urgent," as when one urgently implores someone for something, but here explicitly meaning standing and holding still in the clearing of the truth of Being. Through such formulations, Heidegger suggests that humanity has as its purpose to serve Being, which implies a theology of God or gods or fate, as the language of Seinsgeschick in the later work also suggests, as well as a subjection of the human subject to this divine instance. ${ }^{13}$

Second remark: there remains the complex and often discussed question of Heideggerian resoluteness and the authenticity it is to realize. For resoluteness or decision is perhaps despite everything not so easy to distinguish from a sovereign subjectivity insisting on itself and on its proper identity, in this akin to Carl Schmitt's version of decisionism. The affinities of Heideggerian resoluteness with subjectivity appear, for example, in the sublime distance it takes, on the level of its own Being, from the entanglements of the everyday (even if it remains in fact actively involved with the world), and with the gathering of itself into the "moment." Indeed, the fact that Heidegger wants to exclude 
anxiety from the "moment" of resoluteness as such is perhaps a symptom of this problem. Berthold-Bond discusses this question of the limits of Heideggerian resoluteness usefully, and finds support in many and varied recent readers. ${ }^{14}$ In short, between the resoluteness so prominent in the earlier writings, and the clearing of Being that becomes more central in the later ones (neither of which emphases can do entirely without the other), a certain subjectivity and a certain ontotheology still haunt Heidegger's work. Of course, he himself is capable of acknowledging that he is only trying to break a pathway toward the thinking of Being. The point, therefore, is not to belittle Heidegger for not entirely escaping the limitations he attributes to Kierkegaard. Nor is it to claim that Kierkegaard goes farther than he does in breaking out of the subjectivist form of ontotheology that still guides his brilliant version of radical Protestant conviction. If Heidegger overstates the case both against Kierkegaard and on behalf of his own achievement, and if also his political delusions (from the twenties to the forties and beyond) register his continuing partial adherence to subjectivism and ontotheology beyond and against his strongest insights, nonetheless the continuation and critical renewal of his thinking of Dasein and of the truth of Being, under the powerful influence of Kierkegaard's singular intervention, remain valuable and even necessary today. ${ }^{15}$

This conversation remains of interest because we are living in an age-a post-Enlightenment, ambivalently secularized age-in which we are still caught between, on the one hand, a subjective truth or a subjectivity of truth made possible and necessary by the privatization of faith, i.e. by "tolerance," and on the other hand, a public discourse of rationality, scientific and/or philosophical, that would replace the objectivity of pre-Enlightenment discourses of revelation. Anxiety is in Kierkegaard and Heidegger a "subjective" and "existenziell" state, respectively, that functions as the threshold of a non-subjective absolute, divine and/or ontological, in the one case defined in more religious and particularist terms, in the other case in somewhat more secular and universalist ones. At a moment when the objective revelations are making a public come-back, and 
religion is politicizing itself with a vengeance, maybe a return to their concerns with anxiety is not such a bad idea.

${ }^{1}$ Die Metaphysik des deutschen Idealismus, 26. Citations from this work given below parenthetically in text. Translations my own.

2 Sein und Zeit, 117; Being and Time, 114. Citations from this work given below parenthetically in text, first from German edition, then (after semicolon) from English translation. Consistent with Heidegger's claim about existence in the passage cited here is his indication elsewhere that "the they" or "the nobody" [das Man]-i.e. the answer to the question of the "who" of "everyday Dasein"—is not a "universal subject" $(128 ; 124)$, because this would only be the case if the Being of "subjects" were understood in a manner incompatible with Dasein, namely as "factually objectively present cases of an existing genus [vorhandene Fälle einer vorkommenden Gattung]" (128; 125).

${ }^{3}$ For a rigorous overview of Heidegger's critical approach to subject-centered thinking, and one that usefully understands Heidegger to be thinking not "so much against the subject as that which comes before it," see Raffoul, Heidegger and the Subject (here, 3). For recent collections of essays that re-explore the question of the subject in post-Heideggerian terms from various perspectives, see Cadava et al, Who Comes After the Subject, and Critchley and Dews, Deconstructive Subjectivities.

${ }^{4}$ Emmanuel Lévinas, Totalité et infini, 262 (Totality and Infinity, 235).

${ }^{5}$ When he speaks of anxiety as "freedom . . . entangled . . . with itself" (49), and not with necessity, he is evidently articulating a space between freedom and necessity that, like (or as?) the space between possibility and reality, participates in each (since "entanglement" is a necessity of being bound up with).

${ }^{6} \mathrm{Cf}$. the discussion of the modalities of possibility and reality in the Concluding Unscientific Postscript (282-307), where the ethical and aesthetic positions articulate the two perspectives from which one of these modalities predominates over the other (in the ethical, reality appearing as "higher" than possibility, in the aesthetic orientation the reverse). The reversibility of the hierarchical opposition, or its immanent self-deconstruction, functions at the very center of the articulation of the relation between the ethical and the aesthetic. For a theological discussion of this passage, see James Brown, Kierkegaard, Heidegger, Buber, and Barth: Subject and Object in Modern Theology, 46ff.

7 "The absolute future, holding the abyss of possibility in excess to all calculation or expectation, is the gap that separates the present from its own reality as posited. In this separation of the present from its own reality lies the origin of 
anxiety. To possess oneself is impossible, and yet to flee oneself is equally impossible. One is bound over to oneself, and in being bound to oneself one is bound inexorably to what comes of itself, the absolute future" (191).

${ }^{8}$ One "crucial" difference is that in Heidegger authenticity and the ownmost-and ultimately resoluteness-orient the negotiation of a path through anxiety while in Kierkegaard seriousness and faith play this role.

${ }^{9}$ Cf. Lévinas' remarks in response to Jean Wahl's lecture on "A Short History of Existentialism," where Lévinas emphasizes that Heidegger displaces the notion of a "potentiality which passes into act" (52) by discovering in death the possibility of the realization of "the impossibility of all realization" (52), "the possible as such" thought independently of the act and its finality.

${ }^{10} \mathrm{Cf}$. Lévinas' displacement of this motif in his remarks, in "À propos de 'Kierkegaard Vivant'" (Noms propres, 91; Proper Names, 78), on the "incognito" status that should be accorded to truth as the (persecuted) truth of the Other, beyond all revelation, who puts the ego in question by virtue of its implied infinite responsibility.

${ }^{11}$ Another dimension of Heidegger's critique of Kierkegaard's construal of the "moment" consists in Heidegger's (inconsistently maintained, but explicit) claim that anxiety is to be kept separate from the "moment," because the former "brings one into the mood for a possible resolution" (344; 328), but does not accomplish but only glimpse the possibility of repetition that, when realized, will constitute resolution itself $(343 ; 327-8)$. Whereas Kierkegaard posits that "anxiety is the moment" (81), Heidegger places anxiety just on the threshold of the moment and its resolution, apparently because anxiety (as a mood) is too passive to constitute the more active stance of resoluteness per se. The tension and indeterminacy of the difference between possibility and actualization troubles here Heidegger's already problematic reservations with respect to the relative passivity and subjectivism of anxiety qua mood on the limit of decision.

${ }^{12}$ See Karl Löwith, Martin Heidegger and European Nihilism, 214.

${ }^{13}$ Cf. Lévinas, in "Kierkegaard: Existence et éthique," where (as elsewhere) he defines the dimension of "hauteur" ("height") in terms of the "double mouvement de la responsabilité" ("double movement of responsibility") whereby "Celui dont j'ai à répondre, c'est celui à qui j'ai à répondre" ("The one to whom I am answerable is the same one for whom I am answerable") (Nom propres, 86; Proper Names, 74).

${ }^{14}$ See also the essays by Simon Critchley, Dominic Janicaud, Jean-Luc Marion, and Rudi Visker, in Critchley and Dews, Deconstructive Subjectivities, for 
suggestive analyses of how we might think with and against Heidegger beyond the limits of his attempt to break free of metaphysical subjectivity.

15 And of course, the Adornian, Lévinasian, Lacanian, and Derridian responses to Heidegger's thinking, for example, and to his reinscription of Kierkegaardian anxiety, very much belong to this still necessary conversation.

\section{Works Cited}

Berthold-Bond, Daniel. "A Kierkegaardian Critique of Heidegger's Concept of Authenticity," Man and World (April 1991) 24.2: 119-42.

Brown, James. Kierkegaard, Heidegger, Buber, and Barth: Subject and Object in Modern Theology. New York: Collier Books, 1971.

Cadava, Eduardo and Peter Connor and Jean-Luc Nancy, eds. Who Comes After the Subject? New York and London: Routledge, 1991.

Critchley, Simon and Peter Dews, eds. Deconstructive Subjectivities. Albany: SUNY, 1996.

Heidegger, Martin. Being and Time. Trans. Joan Stambaugh. Revised and with Foreword Dennis J. Schmidt. Albany: SUNY, 2010.

_. Die Metaphysik des deutschen Idealismus. Zur erneuten Auslegung von Schelling: "Philosophische Untersuchungen über das Wesen der menschlichen Freiheit und die damit zusammenhängenden Gegenstände"(1809). Frankfurt am Main: Vittorio Klostermann, 1991.

—_. Sein und Zeit. Tübingen: Max Niemeyer Verlag, 1979.

Kangas, David. Kierkegaard's Instant: On Beginnings. Bloomington: Indiana UP, 2007.

Kierkegaard, Søren. Concluding Unscientific Postscript. Trans. and Ed. David F. Swenson and Walter Lowrie. Princeton: Princeton UP, 1941.

- The Concept of Anxiety: a Simple Psychologically Orienting Deliberation on the Dogmatic Issue of Hereditary Sin. Trans. Reidar Thomte and Albert B. Anderson. Princeton: Princeton UP, 1980.

Lévinas, Emmanuel. Noms propres. Paris: Fata morgana, 1976.

—. Proper Names. TransI. Michael B. Smith. Stanford: Stanford UP, 1996. 
Totalité et infini: Essai sur l'extériorité. Paris: Kluwer Academic, 1992.

—. Totality and Inifinity: an Essay on Exteriority. Trans. Alphonso Lingis. Pittsburgh: Duquesne UP, 1969.

Löwith, Karl. Martin Heidegger and European Nihilism. Trans. Gary Steiner. Ed. Richard Wolin. New York: Columbia UP, 1995.

Raffoul, François. Heidegger and the Subject. Trans. David Pettigrew and Gregory Recco. Amherst, NY: Humanity Books, 1998.

Wahl, Jean. A Short History of Existentialism. Trans. Forrest Williams and Stanley Maron. New York: Philosophical Library, 1949. 